\title{
Historical Unemployment Rate and External Trade in Boyaca 2004-2016
}

\author{
John Jairo Martínez Álvarez \\ Full-time Professor at the International Business Faculty, Santo Tomas University, Colombia \\ john.martinez@usantoto.edu.co
}

\begin{abstract}
Through the historical study of numbers, it will be known how employment, in general, and public employment, in particular, has been suffering a detriment over the years. Likewise, by means of comparative tables, it will be reflected how the department of Boyacá, in Colombia, has been losing ground in the export field, generating lag in the economic activity and a higher unemployment rate, which converges in a low competitiveness index in the country. The economy is nourished by numbers because its strict use allows identifying the magnitude of the economic problems and reduces the uncertainty in decision-making. For which a set of indicators will be observed, such as unemployment and external trade in the department of Boyacá, which make it possible to design, to measure and to evaluate the policies performance for decision making.
\end{abstract}

KEYWORDS: numbers, indicators, unemployment, external trade

\section{Introduction}

The Department of Boyacá has been behind from the others. In the indicators and national study of numbers, it has been very low. So, its results barely affect the national economy. For the same reason, there is contempt about the department contribution, focusing, generally, on the large cities such as Bogotá, Medellín, Cali, Barranquilla and Bucaramanga economic history. Main changes in the unemployment and the external trade variables are examined in order to make them known and to present the results before the academic community. The Department of Boyacá numbers indicate that it is a department which is lagging behind the external sector and employment, by comparing it with other departments in the country. Between 2004 and 2016, period of time for this research, unemployment had a cyclical behavior according to the economic upturn and production moments. It was observed that, in 2004, unemployment presented numbers of $12.4 \%$ and, in 2008 , this unemployment rate dropped to $7 \%$, but it rose again in the following years.

In this research, it is also evident how the Department of Boyacá participation, in terms of international trade, exports and imports, has been reduced by going from exporting $1 \%$ in 2000 , from the national total percentage to $0.6 \%$ in 2011. During this study period, Boyacá stood out in raw materials and products for industry importation, especially, products related to mining and, followed closely by pharmaceutical chemical products and agricultural products.

\section{Macroeconomic context}

Historically, the Department of Boyacá has been rich in natural resources, with a privileged geographical position, where its main economic dynamism is traditional agriculture, in the primary sector, focused on supplying the domestic market, being the capital of Colombia, the main destination for its products.

Before the reception of free market, people talked of growth and economic development at all levels, which would generate more employment and, therefore, improvement of the citizens' quality of life. Nowadays, reality is contrasting what was announced and neither Colombia nor the department have managed to maintain an economic balance, which allows generating greater development and employment. It has been on both sides of the economic models: on one hand, the Keynesian welfare model, which through subsidies, has maintained a policy of equity and resources distribution, but also government assistentialism and populism. On the other hand, the free market designed to give entry to multinational companies, which contribute to the generation of employment and development, has not been sufficient and employment, at national level, has not 
increased and has been stuck in just one digit. In 2013, it stood at $9.88 \%$, but, for the department of Boyacá and its capital, the unemployment rate has been decreasing with respect to their own numbers. In addition to the above, the corrective economic policies applied were contradictory to each other, causing delays in their effectiveness and generating greater uncertainty in the private sector (Fedesarrollo 2010, 2).

\section{Unemployment}

Unemployment is a social phenomenon caused by economic crises or adjustment measures which causes the demand for workers to decrease. Boyacá is a department located in the center east of Colombia, in the Andes mountain range. Its current population is 1,406,000 inhabitants, according to DANE (2015), distributed in 123 municipalities, of which, a little more than $90 \%$ of the municipalities in this department, are in category 5 and 6 . It has an area of $23,189 \mathrm{~km} 2$, corresponding to the $2.03 \%$ of the national territory. It has a high unemployment rate due to the lack of opportunities and, according to the Boyacá labor market indicators during this study period (2004-2016), unemployment had a cyclical behavior according to the economic upturn and production moments. Table 1 shows that, in 2004, the unemployment rate in Colombia was well below departmental unemployment and its capital, Tunja.

Table 1. Unemployment rates

\begin{tabular}{|c|c|c|c|}
\hline & Tunja & Boyacá & Colombia \\
\hline $\mathbf{2 0 0 4}$ & 16,5 & 12,4 & 12,7 \\
\hline $\mathbf{2 0 0 5}$ & 17,3 & 9.0 & 10,33 \\
\hline $\mathbf{2 0 0 6}$ & 18,4 & 10,5 & 11,78 \\
\hline $\mathbf{2 0 0 7}$ & 13.7 & 9,6 & 9,89 \\
\hline $\mathbf{2 0 0 8}$ & 12,3 & 7.0 & 10,61 \\
\hline $\mathbf{2 0 0 9}$ & 13,3 & 9,7 & 11,31 \\
\hline $\mathbf{2 0 1 0}$ & 13,2 & 10,1 & 11,12 \\
\hline $\mathbf{2 0 1 1}$ & 11,9 & 8.0 & 9,82 \\
\hline $\mathbf{2 0 1 2}$ & 12,0 & 7,3 & 9,55 \\
\hline $\mathbf{2 0 1 3}$ & 12,1 & 8,9 & 9,88 \\
\hline $\mathbf{2 0 1 4}$ & 11,6 & 7,5 & 9,1 \\
\hline $\mathbf{2 0 1 5}$ & 10,4 & 6,2 & 8,0 \\
\hline $\mathbf{2 0 1 6}$ & 12,5 & 7,0 & 8,7 \\
\hline
\end{tabular}

Source: Author's elaboration based on DANE and ICER data

According to Farmé (2014), (director of the Employment Observatory in the Externado de Colombia University), recently in Colombia, the unemployment rate has been decreasing, as we can see in Boyacá and Tunja, the trend rose with respect to 2012 and 2013. Although unemployment fell from 2010, standing at Tunja with $13.2 \%$ and at Boyacá with $10.1 \%$, it continues being higher than the national average.

In addition to all of the above, in the Department of Boyacá, people employed in informal areas has been increasing, such as street vendors, magazine sales, clothing, food, selling cellphone minutes, and other informal economy activities. This situation positions the Department of Boyacá among the first places in poverty indexes $(72 \%)$, and, therefore, registering a high degree of intrafamily violence. 


\section{Public unemployment}

The State is the largest employer in the country; currently the number of public employees reaches approximately one million one hundred and seventy-three thousand three hundred and fifty-one (1'173.351) employees (Administrative Department of Public Service 2014), of which the department of Boyacá contributes with approximately 3,200, without counting on those contracted by Special Service Agreement (SSA). When the free market economic model was introduced, public companies started to go private. It has been spoiling public employment little by little, changing the ways of hiring staff and, consequently, reducing the payrolls in the different State entities. It is generating unemployment and the ways of hiring staff through the so-called SSA, Special Service Agreement, which also reduces the overtime compensation and weakens union action.

The different reforms consequences on public employment and the State permissiveness against the exploitation in the less favored workers sectors show that this model benefits from failures and its complacency which also impoverishes its citizens. Rodríguez (2005) states that the sector with the highest job offer in Boyacá is the with the Government, through the mayor's office and the governor's office, despite the continuous and different administrative reforms carried out to dismiss public employees and close down state companies or give them in concession. From the above, Table 2 is presented based on information from the Human Talent Direction in the Government.

Table 2. Elimination of Jobs in Boyacá's Goverment

\begin{tabular}{|c|c|c|c|c|c|}
\hline YEARS & $\mathbf{1 9 9 0}$ & $\mathbf{1 9 9 5}$ & $\mathbf{2 0 0 0}$ & $\mathbf{2 0 0 5}$ & $\mathbf{2 0 1 0}$ \\
\hline MEN & 494 & 547 & 470 & 228 & 229 \\
\hline WOMEN & 480 & 368 & 405 & 328 & 332 \\
\hline RESULT & $\mathbf{9 7 4}$ & $\mathbf{9 1 5}$ & $\mathbf{8 7 5}$ & $\mathbf{5 5 6}$ & $\mathbf{5 6 1}$ \\
\hline
\end{tabular}

Source: Martínez 2015

The previous table shows how, in the course of time, public workers were substantially reduced by almost 58\%, beginning in 1990 with the proposed development plan at that time "economic opening" and until 2010, when the free market was consolidated. Additionally, it is also observed how women have taken precedence in the activities development within the institution.

$$
\text { Public Employment Participation }=\frac{\text { Number of Public Sector employecs }}{\text { Economically active population }}+100
$$

From 1995 onwards, there is a reduction in public sector employees, from 23,018 employees in the department to 3,200, in 2010. That is, in 20 years, it was reduced by $86 \%$, equivalent to 19,818 people in the department of Boyacá who were unemployed in this period of time, due to privatizations and the supposed modernization of the State.

\section{External Trade 2004 - 2016}

The Department of Boyacá has had little export participation evidencing contributions to the national GDP that do not exceed $2 \%$. In the same way, its industrial activity is very low. Although, the 
productive tradition in a peasant economy and the tenacity of its people, as well as the privileged central location and its variety of climates, soils and rivers, are making the department of Boyacá have competitive and comparative advantages, which make it one of the 32 Colombian departments with the best prospects for growth and economic development.

The evolution and structure in the departmental exports during 2014 - 2016 (table 3) reflects the economic activity and the exports decline over time influenced by different domestic and external economic national policies. In those years in the department, quite contradictory variations were registered when moving from a rural economy based on the primary sector to a service economy, supported by the tertiary sector. In 2003, exports decreased by $23.3 \%$ (ICER 2001), in relation to the immediately previous year, dropping them from US\$102 million exported to US\$79,4 as a result of the decrease in exports from the agricultural sector and the retreat in the manufacturing industry, trade, construction and real estate activities. In 2009, exports again fell by approximately $73 \%$ with respect to the previous year and there was a rebound in imports, generating a trade balance in deficit. In the following years 2011, 2012 and 2013, exports maintained a moderate growth while imports grew at a higher rate. Industrial goods exports grew and agricultural products decreased from $12.4 \%$ to $1.7 \%$; "Industrial goods reaffirmed their dominance until absorbing $94.2 \%$ in 2011 , an increase of almost $10 \mathrm{pp}$ since the beginning of the decade. The second factor favored was the exploitation of mines and quarries, which amounted to $4.1 \%$ of the exporting aggregate, "(Regional Center for Economic Studies, p. 43). Only until 2014 and 2015, there is evidence of a recovery in exports and a decrease in imports, generating better expectations for growth and departmental development with agricultural products taking the lead in exports.

Table 3. Boyacá External Trade (thousands of dollars)

\begin{tabular}{|c|c|c|c|c|}
\hline \multicolumn{5}{|c|}{ Boyacá External Trade (thousands of dollars) } \\
\hline & $\begin{array}{c}\text { Non-traditional } \\
\text { exports (Fob) }\end{array}$ & Imports (Cif) & Balance of trade & GDP \\
\hline $\mathbf{2 0 0 4}$ & 83.417 & 17.838 & 65.579 & $\mathbf{- 0 , 9}$ \\
\hline $\mathbf{2 0 0 5}$ & 80.959 & 27.529 & 53.430 & $\mathbf{5 , 8}$ \\
\hline $\mathbf{2 0 0 6}$ & 108.087 & 70.959 & 37.128 & $\mathbf{4 , 9}$ \\
\hline $\mathbf{2 0 0 7}$ & 130.924 & 139.162 & -8.238 & $\mathbf{1 2 , 9}$ \\
\hline $\mathbf{2 0 0 8}$ & 165.545 & 167.376 & -1.831 & $\mathbf{7 , 2}$ \\
\hline $\mathbf{2 0 0 9}$ & 95.244 & 104.230 & -8.986 & $\mathbf{1 . 6}$ \\
\hline $\mathbf{2 0 1 0}$ & 114.965 & 156.282 & -41.317 & $\mathbf{2 , 7}$ \\
\hline $\mathbf{2 0 1 1}$ & 136.277 & 181.919 & -45.642 & $\mathbf{9 , 4}$ \\
\hline $\mathbf{2 0 1 2}$ & 129.894 & 208.614 & -78.720 & $\mathbf{3 , 6}$ \\
\hline $\mathbf{2 0 1 3}$ & 132.698 & 132.912 & -214 & $\mathbf{2 , 9}$ \\
\hline $\mathbf{2 0 1 4}$ & 159.238 & 140.403 & 18.835 & $\mathbf{4}$ \\
\hline $\mathbf{2 0 1 5}$ & 169.208 & 124.123 & 45.085 & $\mathbf{3 , 5}$ \\
\hline $\mathbf{2 0 1 6}$ & 278.854 & 97.1536 & 181.701 & $\mathbf{2 , 6}$ \\
\hline
\end{tabular}

Source: Author's elaboration based on DANE data

The table shows that the exports registered numbers do not have a constant behavior in terms of growth, while imports rise significantly. In 2010 and 2011, there were greater imports at the departmental level constituting, in this way, a detriment in the balance of the department payments and, therefore, a problem which specifically translates into unemployment. In 2016, there was an increase in exports and detriment in imports which helped to consolidate the balance of payments. 


\section{Conclusions}

Within this investigation, it is clear that the Department of Boyacá participation, in terms of international trade, exports and imports, has been reduced by going from exporting $1 \%$ of the national total percentage in 2000 to $0.6 \%$ in 2011. During 2004 and 2012, it was evidenced as the highest unemployment rate in Boyacá, with $12.4 \%$ and $10.1 \%$ afterwards.

The departmental exports evolution and structure from 2014 to 2016 reflects the economic activity and the decline of its exports over time, influenced by the different national internal and external economic policies. The Department of Boyacá's economy has a great strength; its fields are fertile, its waters abundant, its privileged position and its modern road infrastructure allow it to offer its products easily to the national and foreign market.

\section{References}

Banco de la República. Informe de Coyuntura Económica (ICER), varios números.

Cámaras de Comercio de Boyacá, (2015).”Boyacá en Cifras". Recuperado el día 20 de febrero de 2019 de: http://boyaca.gov.co/economico/images/2016/documentos_económicos/Boyaca_Cifras_2015.pdf.

Departamento Administrativo de la Función Pública. (2014). Cífras de la Función Pública. Bajado el 20 de febrero del $2019 \quad$ de: http://www.funcionpublica.gov.co/documents/418537/506955/Cifras+Rendici\%C3\%B3n+de+Cuentas +2015.pdf/b4a58d34-f581-4333-8b53-4763dedf6d3a

Departamento Administrativo Nacional de Estadística (DANE), (2005). Manual de conceptos básicos y de recolección: Encuesta Continua de Hogares-ECH, abril-junio. Bogotá: autor.

Farné, S. (2003). Estudio sobre la calidad del empleo en Colombia. Lima: Organización Internacional del Trabajo (OIT)-Oficina Regional para América Latina y el Caribe. García, G. A. (2005.

Gobernación de Boyacá. (2005). Anuario Estadístico de Boyacá

ICER, Boyacá, (2008). Cuarto Trimestre.

ICER, Boyacá, (2014).Tercer semestre.

Infante, R \& Vega-Centeno Máximo. (2001). La calidad del empleo: Lecciones y tareas. Revista de Economía. Pontificia Universidad Católica del Perú.

Martínez John. (2015). Impacto de las Reformas Económicas Neoliberales en Colombia desde 1990. In Vestigium Ire. Vol.8. PP 78 -91. Universidad Santo Tomas.

Programa de Naciones Unidas para el Desarrollo. Informe sobre el Estado de Avance sobre los Objetivos de Desarrollo del Milenio, 2012. Boyacá.

Parra Torrado, Mónica y otros. (2010). "Análisis y perspectiva de desempleo en los últimos 12 años". Fedesarrollo.

Rodríguez, A. Edilberto. (2005). Perfiles de la economía boyacense. Revista Apuntes del CENES, Universidad Pedagógica y Tecnológica de Colombia. Tunja. 